\title{
Fuga da terra imperfeita: a eterna busca da terra sem mal guarani da Amazônia Meridional
}

\section{Escape from the imperfect land: the eternal search of the guarani land without the guarani of the southern amazon}

\author{
Rosalvo Ivarra Ortiz ${ }^{1}$ \\ Almires Martins Machadd2
}

\begin{abstract}
Resumo: O presente artigo é resultado de uma pesquisa etnográfica e bibliográfica realizada entre o Guarani Mbyá do Pará- Amazonia Meridional do Brasil. Dessa forma, para a elaboração do texto foram analisados vários materiais que foram formulados em outrora acerca da etnia Guarani como Nimuendajú, Shaden, Clastres, Meliá, Chamorro e Litaiff. Assim a nova pesquisa etnográfica comprovou que há diferenças significativas entre as cosmologias Guarani (Mbyá, Kaiowá e Ñandeva), apesar de possuir algumas semelhanças. Portanto, como resultados ficaram evidentes que os Mbyá sempre estão contextualizados com a busca da terra isenta do mal.
\end{abstract}

Palavras-chave: Guarani, Amazônia, Cosmologia.

\begin{abstract}
This article is the result of an ethnographic and bibliographical research carried out between the Guarani Mbyá of Pará-Southern Amazonia of Brazil. Thus, for the elaboration of the text, several materials that were formulated in the past about the Guarani ethnic group like Nimuendajú, Shaden, Clastres, Meliá, Chamorro and Litaiff were analyzed. Thus the ethnographic research proved that there are significant differences between the Guarani (Mbyá, Kaiowá and Nandeva) cosmologies, despite having some similarities. Therefore, as results it became evident that the Mbyá is always contextualized with the search of the land free from evil.
\end{abstract}

Keywords: Guarani, Amazon, Cosmology.

\section{Considerações iniciais}

Considerando o mito como parte do processo constituinte de uma identidade, ele é conhecido, compartilhado em tese por todos os membros de tal sociedade, passa a

\footnotetext{
${ }^{1}$ Possui graduação em Licenciatura plena em Ciências Sociais pela Faculdade de Ciências Humanas da Universidade Federal da Grande Dourados- FCH/UFGD. Atualmente é acadêmico do Mestrado em Antropologia Sociocultural- Linha de Pesquisa: Arqueologia, Etno-História e Patrimônio Cultural pela mesma instituição de ensino, com início em 2017. É membro do grupo de pesquisa do Conselho Nacional de Desenvolvimento Científico e Tecnológico (CNPQ) GIPEDAS - "Grupo Iberoamericano para Pesquisa e Difusão da Antropologia Sócio-Cultural". Possui artigos publicados no Brasil e na Europa. Filho de indígena Guarani. Pesquisa arte, memória e cosmologia Guarani em Mato Grosso do Sul. Bolsista: FUNDECT/MS. E-mail: rosalvortiz@hotmail.com

${ }^{2}$ Graduado em Direito pelo Centro Universitário da Grande Dourados (UNIGRAN, 2004), Mestrado em Direitos Humanos pela Universidade Federal do Pará (UFPA) 2009. Doutor em Antropologia pela Universidade Federal do Pará (UFPA), 2015. Membro do Núcleo Jurídico do Instituto Indígena Brasileiro para a Propriedade Intelectual (INBRAPI). Pertencente à Etnia Guarani e Terena. E-mail: ateguara@gmail.com
} 


\section{LOCALIZAÇÃO DA ALDEIA MBYA- RONDON DO PARÁ}

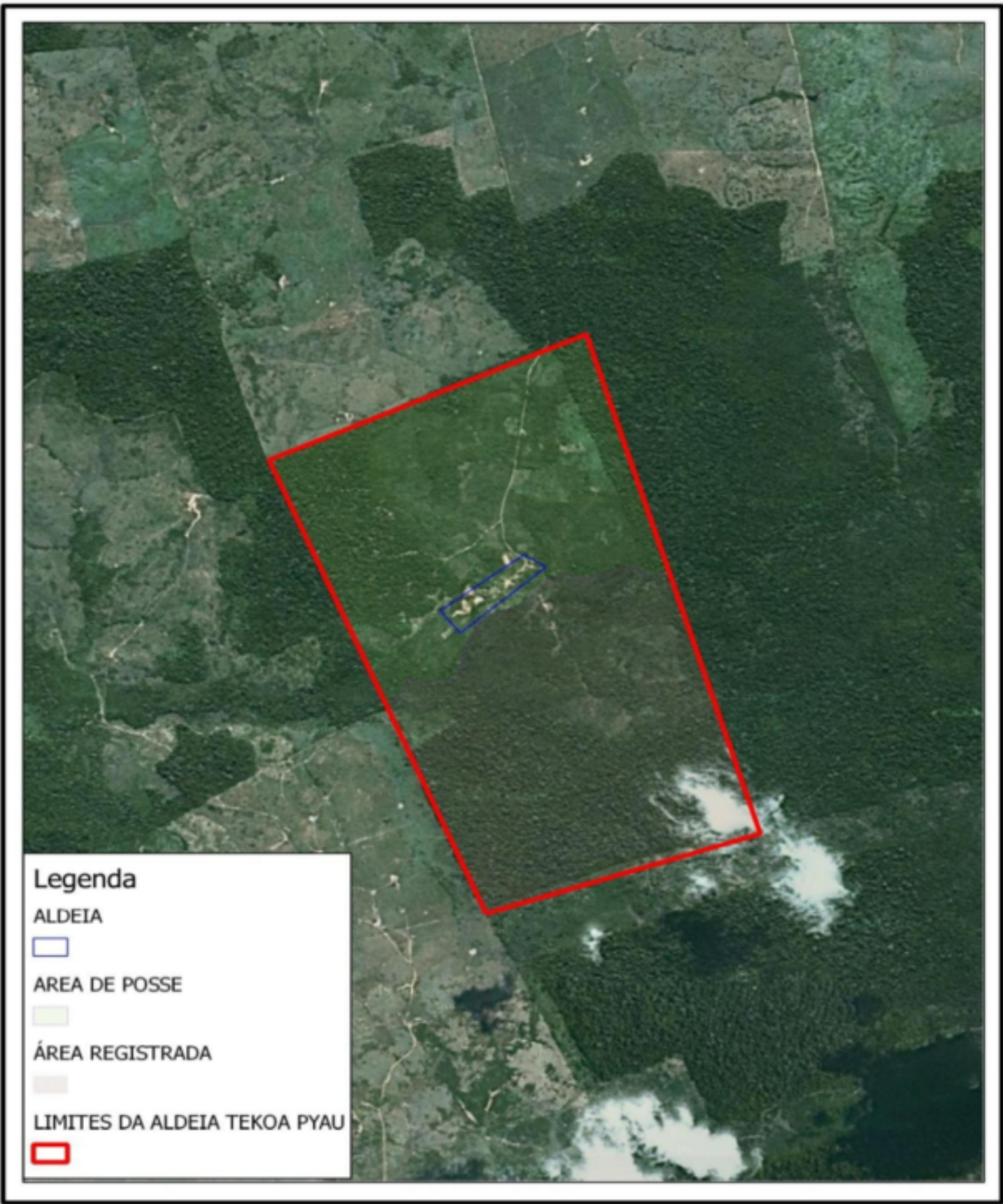


ser uma referência essencial para explicar o ser social ou ao menos indicar os caminhos da construção desse ser. Assim o seu papel é marcar o tempo do inicio, com reflexos no presente, mesmo que não haja provas factuais em como demonstrar e /ou comprovar que os mesmos tenham ou não ocorridos; de relevante mesmo, é que continuam vivos, atuando, explicando eventos e produzindos efeitos de e/no sentido do ser Guarani, assim como reflete no cotidiano de sua socialidade.

No entanto quando proferida a palavra mito, ressoa a princípio com ares de um preconceito, estigma, que induz ao imaginário da fantasia ou um conto, estória desprovida de comprovação. No senso comum reveste-se de roupagem de criatividade, invencionice, com fatos e personagens fantásticos, irreais ou ainda que pertença a uma forma primitiva, irracional de pensar, que deságua em crendices ou folclore. Assim se uma forma de pensar é firmada em "verdades" comprovadas, ao mesmo tempo por contraposição, supõe que a do outro se desqualifica por ser classificada no rol dos mitos. Nesse vertende de pensamento enfatiza Melia:

\begin{abstract}
Pero de qué hablan los mitos? Pues de todo. Nada humano es ajeno. La naturaleza misma está humanizada: sol y luna, estrellas, nubes y vientos, fríos y calores, sequías y diluvios. Por el mito pasa la historia entera de la y el descomer, el caminar o el dormir, hasta las relaciones místicas com los de Arriba, pasando por la organización social y política, las regals de parentesco, las técnicas de producción o el sistema económico, sin descuidar los adornos del cuerpo, las maneras del amor, el arte de la danza y los recursos de la poética (MELIÁ, 1997, p. 30).
\end{abstract}

Toda narração carrega em si uma lógica temporal sobre os acontecimentos de outrora, articuladas para conter em si significações que fazem sentido a quem narra, a quem ouve e com o passar do tempo elas irão sendo ressignificadas, readaptadas, mas sem perder o fio condutor, contendo em seu enredo os limites superados nas experiências vividas, num passado não muito distante ou num passado imemorial. No caso Mbya, assim como para outras parcialidades Guarani, iniciam a partir de um lugar e de um tempo, narradas principalmente por Nhanderu/opyguá, Nhandexy/Kunhã karaí (orientadores religiosos), que tem em si autoridade, idoneidade, pois quase sempre estão visitando essa terra de origem onde habita Nhanderu Tenonde (nosso deus primeiro).

É a narrativa que reacende, instiga e sinaliza por meio de sonhos, para uma caminhada com muitas intencionalidades, um fim especifico; relativiza a realidade do presente 
vivido na terra má, imperfeita, (re)orientam no presente ações, medidas, providencias para se aproximar de um modo de vida desejável e direcionada para a possível iluminação do ser Guarani, através da força de seus Poraei (cânticos) e Jeroky (danças) Nhemb"ê (orações/preces).

Aqui se valendo novamente do conceito Guarani do Oguatá (caminhada), cujo objetivo final é procurar, encontrar e entrar na Yvy Marã“y (terra sem mal), de preferência sem passar pela morte.

Os estudos sobre os mitos Guarani conforme (LITAIFF, 2004, p. 23) abrangem: 1) os considerados sagrados tratam da criação da terra sagrada, a Yvy Tenonde (primeira terra) e do espírito humano, Ne"eng. 2) os considerados não sagrados divididos em dois tipos: a criação da terra nova, yvy pyau, ou segunda terra, a terra atual. Onde se insere a narrativa dos gêmeos ou ciclo dos irmãos e relatos históricos sobre os eventos recentes.

Dessa forma, mesmo que narrativas míticas apresentem aspectos de mudanças, apropriações e ressignificações e incorporem situações advindas das experiências sociais, a elas não são dadas ênfase, não se desfigura a harmonia do todo, pois as narrativas são apresentadas como se elas sempre tivessem sido contadas da mesma maneira e não que assumiram este formato a partir de um grande evento histórico, há reelaborações sim, mas não significa que os elementos novos sejam ressaltados ou destacados, aparecerão na narrativa como possíveis novidades, porem na roupagens de elementos conhecidos e presentes nas narrativas do seu sistema cosmológico como: castigos/benesses, desconfiança/confiança, descrença/crer, Jepotá/Aguyje, a ênfase está mesmo no Teko Vaí (conduta má)/Teko Porã (conduta boa), Anheteguá (certo)/Mba"e Javy (errado), que pressupõe o equilíbrio social. Portanto, no que se refere especificamente à forma como as narrativas míticas são reencenadas, o sentido do conceito de "sociedades frias" de Lévi-Strauss $(1973,1983)$ que se apresentam adequados ao caso aqui discutido, considerando que as narrativas incorporam mudanças sem dizer que o fazem.

A partir de (LÉVI-STRAUSS, 2001), com As Mitológicas, onde o autor procura evidenciar a lógica do sensível, do concreto e do real, presentes nos 820 mitos que analisa em concomitância com o Pensamento Selvagem, lançou-se outro olhar, reconhecendo a importância e relevância da cosmologia como forma de interpretar, entender, facilitando 
e possibilitando uma maior compreensão das especificidades, as diferentes lógicas, nas mais diversas sociedades entre as quais as sociedades indígenas. As narrativas míticas possuem um significado prático para o grupo, como bem lembra Lévi-Strauss ao reconhecer que estes relatos representam um instrumento importante para cada cultura, sobretudo, porque constituem em si inúmeras significações da vida do grupo.

De acordo com (MÉTRAUX 1979, p. 34) discorrendo sobre a natureza ou na tentativa de explicar os fundamentos da criação da humanidade nos grupos Tupi afirma: "os homens surgem, em seus mitos, como contemporâneos dos heróis lendários, não propriamente os heróis-criadores, já os encontrando, em dado momento de suas aventuras, povoando a terra".

Provavelmente o primeiro registro em Guarani com sua tradução, conforme ainda é entendida nos dias atuais, da expressão Yvy Marãe"y (terra sem males), foi efetuado pelo padre Ruiz de Montoya ([1639]1876, p. 209), conforme consta no seu Tesoro de la Lengua Guaraní (Ibi Marãney), como sendo: solo intacto, imbuído de sentido de ser mata virgem. Passado séculos, o termo surge novamente na literatura com Nimuendaju ([1914], 1987, p. 108), afirmando que a procura pela Yvy Marãe"y, seria a motivação que impelia os Apopokuva a caminhar. Ele inaugura o mito acadêmico Guarani, que instigará uma serie de estudos posteriores, estudiosos que pesquisarão o tema com mais profundidade.

Sobre isto comenta a historiadora paraguaia Graciela Chamorro:

\begin{abstract}
Quanto a Nimuendaju, eu destacaria, por um lado, que não se pode desmerecer o significado do fato de ele ter priorizado as informações do âmbito religioso, o que permitiu conhecer aspectos dessa cultura indígena até então desconhecidos e subestimados. Por outro lado, há que se reconhecer que isso deu asas à imaginação de muitos autores e autoras que, tomando como ponto de partida os relatos sobre os povos apapokuva, fizeram desdobramentos exagerados precisamente da "terra sem males", tornando a encobrir esses indígenas como sujeitos de um processo histórico- social (2008, p. 169).
\end{abstract}

Sem sombra de dúvida que é na forma de conceber e entender o universo que sedimenta a abissal diferença entre o pensamento dos indígenas e de outras culturas entendidas como sendo ocidentais ou dos brancos. Essas separam homem da natureza, ele é algo a parte e como tal a explora, transformando-a, ela é apenas uma fonte de recursos minerais, hídricos, combustíveis fósseis, que "promove" o "progresso", con- 
forme o conhecimento cientifico possibilita. Ao contrario os povos indígenas, entendem e concebem a natureza como um ser humano, a mãe terra, que sustenta a vida e como tal entristece, chora, sente dor, sorri, ouve, fala, alegra-se, adoece, enfurece-se, protege e pode morrer; como mãe é parte integrante do corpo social étnico. No entanto nos últimos tempos ela tem apenas murmurado sua dor, pelo mal que os humanos the tem causado ao longo dos tempos em sua história de exploração, indícios de que sua saúde esta muito mal, portanto requer os rituais de cura sem tardar, esta é uma das razões pela qual Nhanderu Ete (nosso pai verdadeiro) colocou o Guarani na terra, para cuidá-la, interagir com a mesma, pois com o fim do Guarani, morre também a mãe terra.

\section{A Tridimensionalidade cosmológica Guarani Mbyá}

Assim para o Mbyá, o conjunto cósmico pode existir em três dimensões ou espaços: (1) Yvy (planeta terra); (2) Yvy Araguyje, Yvy Marãe"Ỹ , Tekoá Amba, Yvy Jú, entendido como sendo o paraíso; (3) Àra Paü (intermediária), diz respeito ao Pará (mar), quando se refere ao paraíso terreno e em se tratando do paraíso celeste, é o cosmo. Dessa forma teríamos três Yvy (terras) distintas: (1) a terra, planeta que habitamos; (2) a terra que fica depois do mar; (3) a Yvy Tenonde (primeira terra criada), morada de Nhanderu Ete (nosso pai verdadeiro) e dos ancestrais, que está acima do cosmos, e espreitam as duas terras.

É pertinente a observação de (MELLO, 2006), quando corrobora que é muito interessante uma vez que entre os subgrupos Guarani (Mbyá, Nandeva, Kaiowá, etc) as diferenças no panteão dos deuses e na configuração dos planos cósmicos, entre outros aspectos, são enormes. Refere-se às distinções entre a mitologia Kaiowá encontradas, por exemplo, em (MONTARDO, 2002) e (PEREIRA, 2004), e a mitologia Mbyá, em (LADEIRA, 1992) e (LITAIFF, 1999). A existência de um plano inferior a esta terra, por exemplo, que está nos Kaiowá (assim como em outros grupos do Brasil Central, como os Araweté e os Kamayurá, entre muitos outros) não é encontrado nos Mbyá e Chiripá. Esta distinção desloca a percepção do "parentesco" cósmico entre os humanos e alguns deuses e espíritos, e reflete-se em condutas rituais e sociais, afastando os Mbyá e Chiripá dos outros subgrupos Guarani e aproximando-os entre si.

A narrativa sobre a Yvy Marae"Y (terra sem mal), é uma particularidade da cultura 
transmitida ao longo do tempo, atravessando gerações, segue fazendo parte dos ensinamentos constantemente lembrados no Opy (casa de ensinamentos) integra os diálogos no cotidiano, é um passado bem presente, influencia na vida social e na construção da pessoa Mbya, na formatação de sua sociedade. Constantemente narrado, ganha versões com alguma variação do Tekoá (lugar de morada), mas não prejudica a essência da mesma, constituindo-se em desafio para o contador costurar passado e presente, sem que perca seu foco. Continua sendo o caminho pelo qual princípios do modo de crer/ser Guarani perpetuam-se no tempo, diferenciando-se nessa constância de fé, com marcas indeléveis na sua pessoa, estabelecendo seu modo de ser e estar no mundo, considerando a convivência em sociedade e com outras esferas socioculturais.

Nos Tekoas (lugar de morar) Mbya Guarani, a narrativa é revestida de uma força criadora, fé, resistência, persistência, adequações, atualizações, conferidas no poder das palavras proferidas principalmente no Opy (casa ritual), atestando uma oralidade sempre presente, explicando e dando sentido à vida e ao mundo em que está inserido. Percorre caminhos e reveste a narrativa (mito), com aspectos de discurso fundador. Para tanto essa afirmação exige os mecanismos da lógica cosmológica, do funcionamento discursivo da narrativa em como se materializa na prática de um povo de tradição eminentemente oral, espraiando-se em todas as suas relações e organização social. Formata e sustenta a sua ordem de racionalidade, especificamente imaginada na lógica religiosa, imbricando em uma de suas características mais conhecidas: a caminhada (Oguatá), almejando a terra sem mal. Concordando com a afirmação de Viveiros de Castro, na introdução a obra de Nimuendaju, (NIMUENDAJU ([1914], 1987), diz que no universo Guarani predomina a teologia sobre a sociologia, o tempo cósmico escatológico sobre o espaço social. Ainda nesse segmento o etnólogo francês Pierre Clastres delineia:

Pobres em mitos, os Guarani são ricos em pensamentos (...). A metafísica substitui o mitológico. Se os Guarani têm menos mitos para nos contar é porque dominam mais pensamentos para nos opor (CLASTRES, 1990, p. 12-13).

Embora fazendo hercúleo esforço para não projetar no presente o passado, não obstante, sou constantemente instado (como acontece na Opy), a compreender os registros orais que o passado circula no presente, na tentativa de conectá-lo a uma ética e etiqueta do ser Mbya, em termos que o faz ser diferente na construção da sua pessoa 
e inevitavelmente perfaz a ideia do ser tradicional no presente. Desconheço outro caminho e inferir sobre o sucesso ou fracasso do esforço deve ser sopesado pelo prisma, em última instância, no terreno da plausibilidade, proporcionalidade, razoabilidade, das possibilidades considerando toda a complexidade e riqueza dos conhecimentos tradicionais associados ou não a natureza ou a sobrenatureza, seja os já escritos ou os proferidos pela oralidade, de conhecimento público ou restrito (Opy), que diz respeito ao ser do Guarani.

Embora nossa educação tradicional Guarani nos lastreie, guie, em muitos caminhos aqui trilhados e de ser testemunha ocular de acontecimentos, na Opy (casa ritual) Mbya, nas Nhanderoga (nossa casa) Guarani ou nas Opy Gussu (casa comunal) Kaiowá, há o premente desejo de descentrar a narrativa ou de fragmentar o poder da quase inevitável autoridade etnográfica e assim, minha Exá (ver), Endu (ouvir) e Japysaka (meditar) a linguagem religiosa, tem o cuidado pela hermenêutica nesta construção do Guatá (caminhar) Mbya, na fidelidade à autoria narrativa dos meus parentes contadores dos eventos Ymaguare Oikova (ocorridos em tempos antigos). Embora meu insight étnico, tento mergulhando no mar do conhecimento oral (Guarani) e escrito (livros e trabalhos acadêmicos), caminhar sem perder de vista os limites que circunscrevem os imensos rios culturais e os portos semânticos que separam e aproximam pesquisador e o parente interlocutor, "fonte", das complexas narrativas criadoras de onde emerge o ser Guarani. A tentativa é de traçar um caminho lógico, costurado, onde evidencie método, estilo, teoria e conteúdo.

Assim o chamado "mito", é para o Mbya Guarani a narrativa que explica o inicio de tudo, o surgimento das coisas num espaço de tempo primordial, de uma realidade que contempla a lógica de seus rituais, a sacralidade que fundamenta sua postura, modo de ser e suas ações na atualidade. Essas narrativas são ricas e complexas, demonstrando a intimidade de suas relações com as suas divindades que se encontram na Yvy Tenonde (primeira terra), fortalecendo dessa forma a tradição secular do Guarani hodierno.

A gênese está no antes do tempo ou eras primordiais, na memória imemorial da narrativa/mito, no momento em que todas as coisas são originadas, criadas; tem-se a narrativa dos acontecimentos como verdadeiro, fidedigno, argumentos de verdade fac- 
tual e irrefutável, vivenciadas pelos primeiros Guarani, razão do selo da ancestralidade, é o poder da palavra ancestral, originária de axiomas que predicam a idoneidade do argumento/verdade, razão pela qual o Guarani hodierno persiste em narrar os fatos acontecidos em outras eras, perpetuados pela oralidade. Lembrando que esta tradição oral e narrativa difere entre os vários troncos linguísticos, assim a Guarani não é a mesma coisa entre os Jê, Arwak, Pano, ou Karib. Essas diferenças também são encontradas entre as etnias da mesma família linguística ou subgrupos, assim há as claramente perceptíveis se analisados, o registrado sobre o Mbyá Guarani e o Apopokuva, em autores como CADOGAN ([1959], 1992), HELENE CLASTRES (1978), PIERRE CLASTRES (1990), SCHADEN (1974 e 1989) e NIMUENDAJU ([1914], 1987).

Ao rememorar o passado criador, a narrativa eiva-se de nuances históricas, ainda que a memória olvide algum detalhe, ela incorpora, contextualiza novos fatos, numa permanente reelaborarão da história, em razão da oralidade ela não é estática, fixa, congelada no tempo. Isso permite uma atualização e adaptação às contingências e aos acontecimentos em dado momento histórico vivido. O discurso sobre a persistência pela permanente busca da terra isenta do mal encontra-se duplamente reiterada: a) representa o Teko Amba (modo de vida celeste), quando a condição humana do Guarani deixará de ser imperfeita; b) retorno ao tempo da primeira terra Mbyá, convivendo novamente com suas divindades. Para o narrador Mbyá Guarani, não há uma discrepância no seu relato, muito menos uma anacronia narrativa, pois o tempo desta difere do tempo cronológico, nem a este se submete.

A Mbo "e"a (professora) Maria narra o evento dos gêmeos, enfatizando que é uma história muito cumprida, mas vô conta assim:

Quando Nhanderu foi embora dessa terra, falou pro filho que tava na barriga de nhandexy, pra ele explicar o caminho pra ela chega até yvy marãe'y. nhandexy, a mulher de Nhanderu, tava grávida, esperava o nascimento de kuaray (sol), naquele tempo, pra fazer filho, era só passa a mão na barriga da mulher e ela engravidava. Nhanderu então pegou a sua rede, $o$ arco e as flechas e foi embora brabo com nhandexy, porque ela fez pouco caso dele. Ele ia caminhando e marcando por onde passava, amarrava penas de arara que ficava pendurada nos galho de árvore. Naquele tempo podia conversa com o filho na barriga né, então nhandexy falou para o filho:

- Vamos atrás de seu pai.

Ela pegou suas coisas e saiu caminhando, procurando o sinal do rasto do marido, ela ia catando as penas de arara que via pendurada nas 
árvores. Kuaray vai conversando com a mãe de dentro da barriga e vai falando pra ela o caminho certo pra caminha. Ele pede tudo que vê no caminho, igual nossos filhos hoje, então ele pede que nhandexy pegue uma flor chamada de kuaray ranga (forma de sol), mas quando ela pegou a flor, foi esporada por mamangá. Ela sentiu muita dor e ficou com muita raiva, por isso bateu na barriga e falou pro filho que não pegaria mais nada. Com raiva da mãe kuaray ficou quieto.

Ela foi andando, andando, até chega numa encruzilhada e aí perguntou: - filho, qual vareda que eu vou?

E kuaray não respondia nada. Nhandexy continuava perguntando e nada. Ela então decidiu seguir caminhando. Ando, ando e logo outra encruzilhada, uma das vareda é bem largo, limpo, parecia bom de caminha nele e o outro era estreito, feinho, cheio de cipó e galho de arvore seco. Nhandexy pergunta outra vez pro filho, qual era a vareda certa, só que agora ela fala mansinho né, passando a mão na barriga. Kuaray ainda tava brabo e não falou nada pra mãe dele, então ela pegou a vareda mais bonita né. Foi andando, andando e logo chegou numa casa grande, tava lá só uma velhinha, ela era avó dos jaguaretê (onça). Naquele tempo jaguarete (onça) era igual à gente. Nhandexy foi chegando na casa e a velhinha perguntou:

- O que tu qué aqui? Meus netinhos são muito perigosos, eles não podem te ver aqui, eles vão come tu. Vai embora daqui.

Mas Nhandexy não quis ir embora e foi ficando lá sentada num toco, por que ela tava muito cansada. Então a vovó jaguaretê pegou uma ojá (panela) e virou de boca pra baixo, por cima de nhandexy para esconde ela dos netinhos que tavam chegando. A xivisada chegou, ficaram farejando o ar e falaram:

- Vovó tem carne aqui? Tu tem carne vó? Ela repondia:

- Como que vô te carne aqui se eu não aquento i no mato caça?

Os outros xivi (onça) foram chegando e perguntavam a mesma coisa e ela respondia a mesma coisa:

- Tu é que foi caça e me pergunta de carne?

Então um xivisão (onça grande), o mais velho do bando chegou e foi falando:

- Ta cherando carne aqui.

Foi revirando a casa, chegou na ojá (panela) e a desvirou, achando Nhandexy e matou ela repartindo com seus outros irmãos. A placenta junto com kuaray (sol) foi dada para a vovó comer, ela não tinha mais dente né. Ela falou:

- Vou assar essa criança.

Ela pôs no fogo e o fogo apagou. Resolveu então ferver, mas quando mergulhou kuaray na água fervendo, a água ficou geladinha. Aí a vovó falou:

- Vou socar no angu'á (pilão).

Mas não deu muito certo, kuaray rolava pra lá e pra cá e ela não acertava socá. Ela decidiu que ia espetar num pau, mas o espeto nem arranhava a pele dele, aí ela falou:

- Vou por numa peneira para secar e ele vai ser meu mymbá (animalzinho de estimação).

Kuaray ficou seco, levantou e saiu andando, brincando no terreiro, ao redor da casa. Ele foi crescendo, crescendo, porque ele andava e crescia, e o que ele via, ele dava nome, ele já falava e foi assim que ele deu nome pra tudo. Então kuaray pediu ao seu avô jaguaretê (onça), que fizesse um arco, com bastante flecha pra ele caçar. O avô fez flecha pequena, pra matar passarinho. Aí ele sempre matava passarinho para os xivi come. Quando foi chegando na idade de minino pra homem, 
ele fez um arco maior e sentiu vontade de ir caça mais longe. Aí foi andando, andando e ele viu uma mata grande, depois ele ia direto caça nesse lugar. Pegava cipó imbé e amarrava um montão de passarinho e levavam pra velhinha comer. Um dia ele falou que tava se sentindo muito sozinho e que queria alguém pra companhia, não queria viver mais só. Aí com o poder dele, ele gerou o irmão dele, Jaxy (lua).

Um dia o kuaray convidou jaxy para ir caçar mais longe. Nem ligaram para os conselhos da avó que dizia:

- Eu não quero tu entrando naquele mato grande.

Lá era um mato muito bonito, bem fechado e a curiosidade atiçou os dois para ver o que tinha ali que sua avó não falava para eles. Chegando lá viram um monte de parakau (papagaio), muito colorido, comendo o fruto do yva'á. Combinaram que cada um ia para um lado e, mais adiante se encontrariam. Jaxy não era bom caçador, era muito atrapalhado, muito ruim de pontaria. Kuaray ao contrario era muito bom caçador; Jaxy então ele tentou flechar um parakau e errou a flechada, então ouviu parakau fala assim:

- Tu ta dando de come pra quem comeu tua mãe.

Jaxy (lua) ouviu e tremeu de medo, correu chama Kuaray (sol) e falou pra ele, parakau falou comigo. Os dois foram para onde tava os parakau e Kuaray falou para Jaxy:

- Atira de novo, mas não é para acertar.

Ele flechou e errou, mas passo pertinho do parakau (papagaio) e ele falou de novo:

- Tu ta dando de comer pra quem comeu tua mãe

Foi aí que Kuaray entendeu tudo e chorou muito. Explicou para Jaxy o que tinha acontecido e o que o parakau falou pra ele e os dois choraram muito o dia inteiro. No fim do dia pararam de chorar e com um sopro Kuaray devolveu a vida aos passarinhos que havia matado pra levar para os xivi e pra cada pássarinho que saía voando ele dava um nome. Foi assim que apareceu os passarinho que conhecemos hoje. Mas pra não chegar sem nada em casa, os dois levaram só um beija-flor. Ao chegar na casa, os avós perguntaram por que não trouxeram nada. Os dois falaram que levaram esporada de káva (marimbondo), e que ficaram com os olhos inchados e não podiam ver nada. Os avôs falaram que pela amanhã iam para o mato queimar a káva. Eles tavam desconfiados que os dois pudessem ter descoberto que foram eles que comeram Nhandexy. Logo que chegou em casa kuaray, procurou os ossos de sua mãe no terreiro, achou na beira do mato. Kuaray falou para seu irmão:

- Eu encontrei os ossos de nossa mãe, ta tudo espalhado, vamos ajuntá?.

Kuaray falou para jaxy que quando juntasse os ossos e a nhandexy vivesse de novo, que jamais dissesse:

- Eu quero mamar! Eu quero mamar!

Por três vezes kuaray juntou os ossos da mãe, três vezes jaxy pediu para mamar. Na última tentativa, sua mãe ressurgiu inteirinha. Jaxy gritou:

- Eu quero mamar.

Novamente a mãe virou um monte de ossos. Foi assim por mais três vezes. Então, mais uma vez, kuaray juntou os ossos e falou:

- Agora vou fazer um animal.

E dos ossos da mãe surgiu uma paca que correu para o mato. Falou para jaxy: "

- Vamos fazer um mondé (armadilha) para pegar os jaguaretês (onças), vamos fazer bem no começo da vareda deles. 
Então foram fazendo, aí os xivi viram os dois fazendo o mondé e perguntaram o que era aquilo. Karay falou:

- É um mondé para pegar ratos.

Os jaguaretê sorriram de rolar no chão, fizero pouco caso do mondé porque era feita de sabugo de milho e não ia pegar nada, mas na verdade era um pau muito grande e grosso, o poder de kuaray é que disfarsava o mondé. Então kuaray esperto falou para um jaguarete:

- Se não vai pega nada, então entra aqui para experimentar.

Sorrindo, o jaguaretê entrou e morreu preso no mondé, os dois pegaram o corpo do jaguaretê e jogaram num poço. Com esperteza repetiram essa conversa pra vários deles, até que quase todos morreram na armadilhazinha de kuaray. Só que um dos jaguaretê viu quando um deles caiu no monde, não quis entrar na armadilha e foi embora. Quase todos morreram, sobrou apenas um velhão e as fêmeas. Voltaram para casa dos avós, deitou na rede imaginando um jeito para matar os outros que sobraram. De manhã os dois foram para o mato e trouxeram guavirova para os xivi, a guavirova não existia, foi criada naquele instante por kuaray. Os jaguaretê comeram tudo e acharam muito gostoso, então a avó falou para eles que pela manhã fossem com seus irmãos jaguarete buscar mais guavirova no mato. Kuaray falou:

- A guavirova fica do outro lado do rio, pra catá tem que fazer uma ponte. No outro dia pela manhã, chegando na beira do rio, kuaray pegou seu arco e esticou sobre o rio, segurando numa ponta e jaxy na outra. Os xivi começaram a passar sobre 0 arco em forma de ponte e kuaray deu um sinal para jaxy e viraram o arco para que os jaguaretê caíssem na água. Os que caíram na água se transformaram em ypo (animais aquáticos). Como jaxy é atrapalhado, virou muito devagar seu arco, um xivi grudou nele e saiu no seco. Ela tava grávida, se salvou e ganhou um monte de filhotes e um deles era um macho, é por isso que existem onças até hoje. Kuaray ficou muito bravo com jaxy, deixou ele num lado do rio e seguiu caminhando pelo outro. Mas, mesmo assim eles continuavam conversando. No caminho jaxy topou com uma palmeira carregados de frutos aguaí.

- Que fruta amarela é essa?

- É o aguaí, respondeu kuaray e pediu para ele juntar as sementes de aguaí e pôr fogo. As sementes começaram a explodir como pipoca e ele passou para o outro lado do rio. Os dois irmãos passaram a caminhar juntos. No caminho, berando o rio, kuaray balançava as varas de bambu e quando as folhas caíam se transformavam em pirá (peixes). Continuaram andando e viram o anhã (espírito mal, diabo) pescando.

- Tu fica aqui. Disse kuaray para jaxy.

- Eu vou engana o anhá.

Então foi entrando devagarinho na água, sem fazer barulho, tirou a isca e puxou o anzol de anhá, ele assustou e deu uma fisgada, mas kuaray muito esperto escapou. Jaxy quis fazer igual o irmão fez, mas foi avisado pelo irmão:

- Cuidado, tu não coloque o anzol na boca.

Jaxy imitando seu irmão mergulhou bem devagarinho, chegando até o anzol do anhã. Como ele é desastrado, quando tentou tirar a isca do anzol, anhã fisgou, pegou jaxy e o trouxe para fora da água. Pensando que fosse um peixe, anhã colocou jaxy no ajaka (cesto) e foi pra casa. No outro dia cedo, kuaray foi na casa do anhã, chegando lá ele viu jaxy sendo cozido. Anhã falou para ele entrar, sentar e deu comida, Kuaray agradeceu dizendo que só queria os ossos completos com mbaipy (massa de milho). Depois de comer toda a carne, anhã deu para ele os ossos com mbaipy, com isso ele fez o miolo da cabeça de jaxy. Juntando 
os ossos e o mbaipy, fez de novo o corpo de jaxy, um corpo novo, sem mal, já não era mais imperfeito, desastrado.

Os dois irmãos foram embora da casa de anhã, foram caminhando pela floresta e seguidos por anhã, que queria mata e come os dois. Kuaray falou para o anhã:

- Vou fazer um animal de caça para você comer.

Ele pensou num pé de cedro e um cedro cheio de frutos apareceu aí ele subiu no cedro e pediu para o anhã que ficasse de baixo da árvore, foi balançando os galhos e os frutos do cedro caíram em forma de quati. Anhã foi catando a quatizada até enche o ajaka e depois foi embora e os dois pegaram a caminha outra vez. Depois de ter feito tudo o que existe kuaray sentiu vontade de ir atrás do pai dele e para subir no céu atirou uma flecha que grudou no céu, atirou outra e foi emendando uma flecha na outra, foi subindo e enquanto subia ia tirando as flechas, chegou na yvyju (terra dourada) e continua vivendo lá até hoje.

O pensador Ciccarone, ao fazer menção ao tempo Mbya, afirma:

"[a] idade mítica dos Mbya é um elogio das figuras dos movimentos: auto-evolução, desdobramento e expansão constroem a anatomia mágica da gênese e o modelo ordenador do cosmos; é através dos seus movimentos específicos que os pares das almas divinas, que se incorporam nos indivíduos, são representados; a caminhada é a ação paradigmática da criação do mundo terreno, da existência do indivíduo e da sociedade, sendo as migrações interpretadas como suas variações mítico-históricas; enfim, a condição ontológica da mudança, o vir a ser outro, como um estar numa tensão, num equilíbrio sempre precário entre os extremos do animal e do divino, portanto constitutiva da humanidade, sugere que é em termos dinâmicos que precisamos pensar o universo cultural e social dos Mbya (CICCARONE, 2001, p. 350).

A contagem do tempo Mbya, se dá de forma diferente do calendário romano/cristão, que traça uma linearidade através dos dias, meses, anos, décadas, séculos, milênios, contando o tempo como antes de Cristo (AC) e depois de Cristo (DC). A formatação da contagem do tempo Mbya Guarani, é circular tendo o seu eixo/ponteiro central no tempo existencial da Tekoá Ambá (morada celeste), que o faz circular na terra em forma de ciclos, como numa estrada de mão dupla, num movimento de ir e vir umbilicalmente conectados, em sintonia com os ciclos da mãe natureza e com a essência de Nhanderu Ete (nosso pai verdadeiro), o ser supremo, criador de todas as coisas e este ensinou que o tempo existe em dois momentos distintos: Ara Pyau (tempo novo) e Ara Ymã (tempo antigo/velho), ambos convivem entre si.

A terra da plenitude, terra sem mal, terra dourada, é um aspecto da crença genuinamente Guarani, embora outros povos façam menção a mesma ou que a tenham em suas narrativas, ela não alcançou a dimensão do significado que tem para o Mbya de 


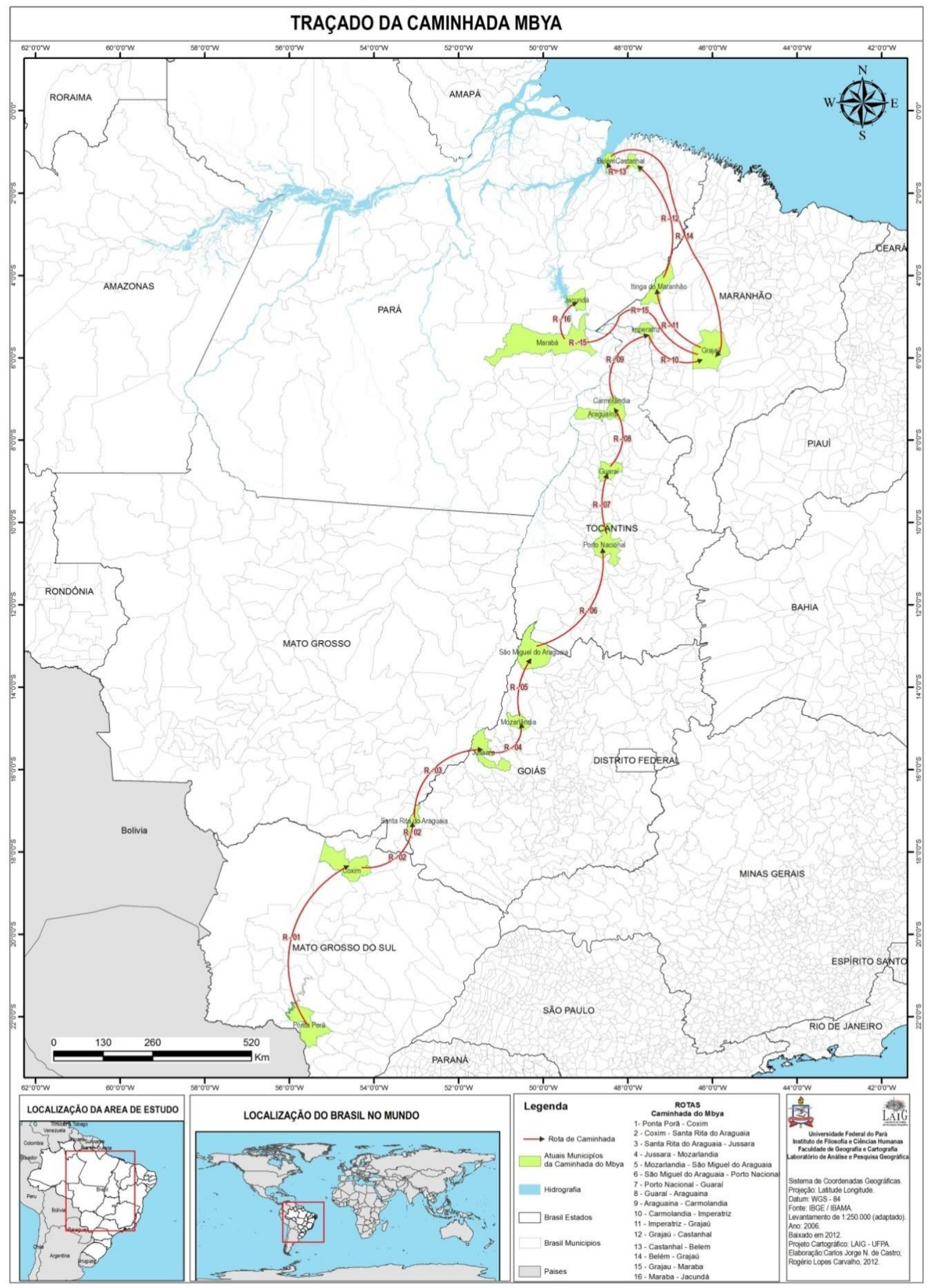


ontem e de hoje. Assim já na década de 1960 o etnólogo da USP Shaden sintetiza:

De um lado temos os referidos Guarani Mbya de Guairá cuja vida mental o papel do cataclismo do futuro é nulo ou quase nulo e para os quais o ideal de Paraíso continua essencialmente religioso, identificando um estado mítico de bem aventurança obtido em recompensa de um cultivo especial de vivencia sobrenaturais e de uma conduta virtuosa, estado que se refere menos a condição de e a existência física do que ao destino da alma. Por outro lado os que já chegaram ao mar ou que estão a caminho, e que encaram o Paraíso antes de mais nada como lugar de refugio e segurança com condições de vida ideais. Esse sentido dado ao mito decorre da ativação da crença na destruição do mundo através das experiências religiosas de determinados feiticeiros (SHADEN, 1962, p. 70).

Dessa forma a transmissão de conhecimentos sobre a cultura, os ensinamentos contidos nas narrativas feitas na Opy, compõe o "código" de conduta e o modo de ser que deverá ser imitada, a filosofia de vida deve ser posta em prática pelo ouvinte, considerando que a observação desses mandamentos o tornará mais próximo, intimo de seu deus, recebendo deste por meio dos sonhos, as orientações para um conviver cotidiano ou iniciar o Guatá (caminhar). No passado, as crianças não entravam na Opy, por serem consideradas vulneráveis, inocentes, correrem o risco de ser acometidas de males trazidos pelos adultos. O interior da Opy (casa ritual) é considerado um lugar de cura do corpo e do espírito, razão de ao fumar o Petinguá (cachimbo), criando uma bruma de fumaça (imitando a celestial), pela qual se obtêm livramento/cura dos males, tanto físico quanto espiritual.

Observando o prescrito nesse "código", sua influência recairá sobre suas relações com outrem e o modo como praticará suas ações e ainda na forma como fará suas roças, construindo suas casas, levantando um Tekoá (lugar de morar), condicionado a apresentar certas características ecológicas (fauna e flora) que pressupõem o bem viver, aproximando o máximo possível das características da $Y v y$ Marãe "Y celeste, porquanto esta terra, depois da chegada do europeu teve sua exponência do mal maximizada, exigindo do Guarani maior empenho em equilibrar as forças, para evitar que esta terra se torne em uma Yvy Axy (terra de dores), por completo. O repentino processo do contato com o europeu implicou imediatamente em conviver com explorações, doenças estranhas, ludibriações, guerras, escravização, perseguição, redução da pessoa a um ser servil, sem alma, cujo único interesse despertado era como mão de obra gratuita, 
disponível.

\title{
2. Mudanças comportamentais e organizacionais forçadas: violências e escravidão
}

Sobre esse encontro com inúmeras variações para a transformação e mudanças, considerando o choque do encontro de culturas, é esclarecedor o ponto de vista de Michael Taussig, que discorrendo sobre o confronto de índios e colonos perto das cabeceiras do Amazonas, na tentativa de entendê-los e explica-los, delineia-os como:

\begin{abstract}
Novos rituais, ritos de conquista e formação de colônias místicas de raça e poder, pequenas derramas da civilização talhando a selvageria que não misturam nem homogeneizam ingredientes dos dois lados da linha divisória colonial, mas em vez disso ligam as visões dos índios sobre as visões dos brancos a respeito dos índios às visões dos brancos sobre as visões dos índios a respeito dos brancos (TAUSSIG, 1993, p. 109).
\end{abstract}

A nova situação em razão do contato, o obriga a repensar, recriar, ressignificar, incorporar, maneiras de superar os obstáculos, sobreviver, potencializando as características que o tornam um Avá te"ê (guarani idôneo e autentico, verdadeiro). É a necessidade premente de estabelecer o Nhandereko (nosso modo de ser) como meta de vida e por ser o caminho para alcançar a Yvy Marãe"Y (terra sem mal), pois a terra má está apresentando estertores de morte e o caminhar representa em outro sentido alcançar o Aguyje (plenitude).

O Nhande Roviá (nosso modo de acreditar) é de suma importância na vida do Mbya, guardadas as proporções é sua riqueza maior que deve ser protegida, escondida, porquanto sagrada, única e por isso deve ser evitado interferência, ingerência ou algo que venha desvirtuar o Nhandereko (nosso modo de ser), é a memória coletiva expressando um passado, que emerge no presente, nas narrativas dos mais velhos, manifestando a sabedoria contida nas bibliotecas/museus vivas da comunidade.

Entendia-se que a terra era até então imperfeita, mas com condições de obter o bem viver, com a chegada dos europeus ela passou a ser imperfeita e cheia de males; o encontro do chamado homem "primitivo", nas terras do novo mundo, com o "civilizado" europeu, ocorria sempre com a marca da violência, seja ela sutil ou explícita.

No caso dos jesuítas, a violência teve seu ponto forte, na criação de uma nova língua, o Nheengatu (fala boa), tentando suprimir as línguas nativas, substituindo por 
outra semelhante, com isso a imposição partia daqueles que em tese, deveriam ser os "protetores" do Guarani. Assim passaram por diversas transformações de usos e costumes, como por exemplo, as vestimentas, deixando de usar o Tambéope (tanga Mbya), para usar as roupas espanholas e portuguesas, viver em casas de famílias nucleares em lugar das casas comunais, restrições de liberdade de ir e vir, professar outra "religião".

Os primeiros contatos com os habitantes do velho mundo e suas consequências nefastas e o ponto critico, foi a proibição de falar a língua própria, suprimindo rituais e impondo restrições para que as narrativas não acontecessem, por serem consideradas pagãs pelos cristãos, e claro impuseram outra lógica de entender e ocupar o tempo e o espaço. No viés dessa ideia o jesuíta e antropólogo espanhol radicado no Paraguai Meliá explicita:

\footnotetext{
Um livro impresso na lìngua guarani pelo padre J. Insaurralde chamado "Araporú aguiyey habá" (Do uso perfeito do tempo - edição de 1759) apresenta na capa o seguinte texto: "En estos livros enseña El autor a los indios, cómo pasar el día íntegro santa y dignamente, ya sea trabajando en casa, ya cultivando el campo, ora camino de la iglesia o asistiendo a la misa(1988, p. 211).
}

Ao chegar à América o conquistador europeu depara-se com a cultura Guarani estruturada, não a compreende, demonstra indiferença ao que vê e pouco interesse terá ao longo da colonização, para reconhecer outra alteridade, razão do extermínio de muitos povos indígenas. Inicia-se no Século XVI por Espanha e Portugal, o processo de conquista, exploração e dominação das novas terras, por meio de três formas distintas com diferentes interesses: pelo missionário Jesuíta; o "encomendero" espanhol; e o bandeirante paulista. Para os missionários os índios representam objeto de catequese, almas a serem salvas para Cristo; para "encomenderos" e bandeirantes, com pequenas variações, eram tão somente mão-de-obra escrava, disponível e abundante. As bandeiras direcionavam as suas investidas sobre o território Guarani, dentre os inúmeros grupos étnicos, foram os que incisivamente sentiram a predação dos bandeirantes paulistas, é neste contexto que se aliam aos padres para se proteger e enfrentar tanto paulisas, como espanhóis. Irão formar as reduções, povos ou doutrinas, como eram usualmente denominadas as missões Jesuíticas onde, em grande número, eram reunidos os Guarani em processo de catequese. Esses que passaram a viver nas reduções eram chamados de índios missioneros ou reduzidos, de alguma forma encontraram refúgio, "proteção", 
contra a avidez dos conquistadores, tanto nas reduções espanholas como na de portugueses.

Mesmo havendo uma caça sistemática ao Guarani, houve os que conseguiram escapar ao apresamento, fugindo, embrenharam-se nas florestas escondendo-se em locais de difícil acesso, como dirimi Meliá:

Durante la época colonial, a lo largo del siglo XIX y hasta La actualidade, hubo grupos guaraní que conseguieron sobrevivir libres del sistema colonial. Selvas relativamente alejadas de los centros de población colonial, poco o nada transitadas por los "civilizados", los mantuvieron lo suficientemente aislados para que pudieron perpetuar su "modo de ser" tradicional. Considerados apenas como sobreviventes de un mundo ya superado, fueron denominados genéricamente Kaygua" y "montaraces". Apenas conocidos, solo fueron raramente visitados por algún que otro viajante em el siglo XIX y pudieron pasar tranquilamente hasta el siglo XX sin especiales interferencias exteriores (MELIÁ, 1991, p. 18).

O contato com o europeu fazia-se acompanhar, de doenças infecciosas, as guerras de extermínio, escravização, mudança da paisagem em forma de desmatamento, fortes motivos para a desterritorializaçao ou fuga dos locais de ocupação ao tempo da chegada dos invasores europeus, seja no litoral ou os localizados nas margens dos grandes rios. Os povos indígenas, entre os quais o Guarani, empreendia uma dispersão forçada em direção às zonas de difícil acesso, para se esconder e continuar a exercitar o modo de vida que o caracterizava como Guarani.

Outra faceta materializada do mal era as encomiendas, de acordo com (MONTEIRO, 1992, p. 482); o que mais afetou a organização político-social Guarani neste período foi primeiramente o "servicio personal", baseado na exploração do trabalho indígena. O costume Guarani de "dar sus hijas o esposas" para estabelecer relações políticas de serviço e reciprocidade baseadas em obrigações por parentesco entre as linhagens das aldeias, foi habilmente aproveitado pelos conquistadores. Ao serem oferecidas as mulheres Guarani para os cristãos, constitui-se o serviço por parentesco para o beneficio dos espanhóis, o qual foi chamado de "yanaconato" (SUSNIK, 1965, p. 1-10). Outro meio utilizado pelos colonizadores foi a "saca de mujeres", ou seja, a utilização da guerra para a obtenção de esposas, chamadas nos primeiros momentos da conquista como "rancheadas". Estas duas práticas, o "yanaconato" e a "saca de mujeres", debilitaram o potencial biológico e econômico das antigas comunidades pela falta do 
componente feminino, provocando também a reagrupação e redução a pequenos grupos domésticos como chamou atenção Susnik (1965). Estas práticas foram à base do sistema de encomiendas, implantado no século XV, foi também a primeira tentativa de legalizar a exploração da mão de obra dos povos indígenas e teve o seu declínio no final do século XVII.

Em relação à colonização portuguesa afirma Darcy Ribeiro:

\begin{abstract}
Milhares de índios foram incorporados por essa via à sociedade colonial. Incorporados não para se integraram nela na qualidade de membros, mas para serem desgastados até a morte, servindo como bestas de carga a quem deles se apropriava. Assim foi ao longo dos séculos, uma vez que cada frente de expansão que se abria sobre uma área nova, deparando lá com tribos arredias, fazia delas imediatamente um manancial de trabalhadores cativos e de mulheres capturadas para o trabalho agrícola, para a gestação de crianças e para o cativeiro doméstico (RIBEIRO, 1996, p. 99).
\end{abstract}

$\mathrm{Na}$ atualidade o mal se apresenta na forma de estar segregado, confinado, espremido, amontoado em diminutas reservas indígenas, limitado pelas cercas das fazendas que cerceiam os caminhos, as caminhadas, a circulação, a movimentação pelos Tekoas, reduzindo a quase nada o outrora Tekoa Guaxú (grande território). O mal na terra acentuou-se com o inicio do sistema colonial, potencializado com força inusitada e formas inéditas, como pestes, escravidão ao estilo europeu, cativeiro e perseguições. A história colonial representou para o Guarani, uma sucessão e progressão de males, com ares de infinitude e crueldade sem limite. No entanto, o mal acentuado a potencia máxima é negar a terra ao Guarani. O Mba"e Megua (a coisa ruim, mal), cobre tudo, domina tudo, espraiou-se pela terra. Isto é constatado em razão de o Guarani nunca antes estar tão desterrado, estrangeiro em sua própria terra, o temor é que viva e presencie o dia em que só haverá o mal e o mesmo um sem terra, nada poderá fazer. Então, os cânticos, as danças, os rituais, a alegria e a esperança cessarão, nesse dia haverá somente o silencio do fim, pois já não haverá mais palavra, a fala da alma esvaiu-se, recolheu- se a sua origem.

Em razão disso, afirma SOUZA LIMA:

Neste sentido, tenho desejado entender como algumas das melhores intenções de que se revestem os "brancos" em seus contatos com os ìndios têm redundado na atualização de formas tutelares e clientelísticas. E não desconheço que paternalismo, tutela, clientelismo são algumas 
das categorias nos jogos de acusação que os participantes do "mundo do indigenismo" atiram com facilidade uns aos outros, sejam índios ou brancos, antropólogos, advogados ou dotados de qualquer outra formação, missionários ou leigos, funcionários governamentais ou não. Se tenho pesquisado sobre a administração pública é porque, dentro de um Estado nacional como o que se procurou implantar no Brasil desde o século XIX, ela é um dos principais vetores cotidianos das formas de dominação. Meu intuito é não só o de refletir intelectualmente, mas também de pensar que posturas e medidas podem ser adotadas para tentarmos estabelecer algumas vias de superação deste aparente círculo fechado (SOUZA LIMA, 2002, p. 04).

Ao longo dos séculos de contato com os habitantes do velho mundo, na terra brasilis com os portugueses e com os espanhóis na região da bacia do prata, induziram a mudanças, situações que apresentavam ares de irreversibilidade fatal ao Guarani, destacando a progressiva diminuição demográfica, o condicionamento a terras diminutas, cisões causadas pelo dissenso que redundou em crises políticas internas, com disputas acirradas pela liderança e o choque cultural causado na e pelas reduções jesuíticas, com possíveis impactos sobre o Nhandereko (modo de ser) e Nhande Jeroviá (modo de crer) Guarani.

Uma tensão sempre presente paira sobre e na imposição de limites territoriais com a demarcação de terras para o Mbya Guarani e consequentemente acompanhada de marcos limítrofes, do cerceamento com placas ou cercas de arame farpado. No entanto a lógica Mbyá esta lastreada na concepção de liberdade e o território, sem limites que dificultem o Guatá (caminhada). Embora aparente uma contradição, os limites e as cercas não são referência de ou para a configuração de um território, se as mesmas são necessárias, não impedem a caminhada, apenas dificultam, sendo ignoradas e transpostas o tempo todo, pois o que determina o limite da territorialidade são as relações de afinidade ou inimizade, dado que as fronteiras étnicas são fluidas.

Os rituais constituem o mais forte elemento na organização social, integração, equilíbrio das relações com a natureza e entre o mundo terreno e o mundo das divindades. Manter em equilíbrio os mundos é viver de acordo com o nhandereko (nosso modo de vida), entendido como os pressupostos éticos e morais do teko porã (conduta boa), que permite a consolidação de um teko marangatu (conduta sagrado, santa), expressa através das ações e modo de proceder para evitar que a terra sofra males que, em última instância, poderiam antecipar o cataclisma que destruirá o mundo conhecido. 
A terra é entendida como a criação de Nhanderu Vussu (grande pai), destinada aos cuidados do guarani, dessa forma, a relação com a terra assume sentido filial, não pode ser considerada como parcela ou como propriedade cuja posse estaria nas mãos de um indivíduo ou de um conjunto destes. Há uma insistência no pertencimento a terra e esta é um ser vivente, é a mãe terra. Nesse sentido é a escrita da carta compromisso da Comissão de Lideranças e Professores em Defesa dos Direitos Guarani Kaiowá:

Carta Compromisso de Yvy Poty Em defesa da VIDA, Terra e Futuro Terra indígena Amambaí, 17 março de 2007:

Nós, do povo Guarani, desde os tempos quando nasceram nossas raízes mais profundas, acreditamos que a natureza é vida, assim como a terra é o chão onde pisamos, com muita firmeza, seguro e sem medo. Para nosso povo não é possível esquecer que a terra é o suporte que sustenta toda natureza, toda vida, porque depois que Tupã fez a natureza percebeu que não tinha quem admirasse os rios, a mata e as montanhas. Foi daí que Tupã pensou e criou o Guarani para admirar toda a beleza que fez.

Por isso, nós somos a flor da terra, como falamos em nossa língua: Yvy Poty. Fomos criados pela natureza, por isso ela está sempre a nosso favor, nos ama, nos alimenta e dá a vida por nós, seres humanos. A água, tão preciosa, sem cor, sem cheiro, cristalina, que vive dentro da gente, respira em nosso corpo e evapora no ar. Formando nuvens de amor de onde cai a chuva para enverdecer as matas, crescer os brotos; as flores para perfumar o universo e alimentar as abelhas que fazem o doce mel; e as frutas para alimentar os pássaros e outros animais.

O mato traz sombra e vitamina para terra e os rios que correm dentro do corpo da terra, como o sangue em nossas veias. Mas a maldade cruel faz o fogo da morte passar no corpo da terra, secando suas veias. $O$ ardume do fogo torra sua pele. A mata chora e depois morre. O veneno intoxica. O lixo sufoca. A pisada do boi magoa o solo. O trator revira a terra. Fora de nossas terras ouvimos seu choro e sua morte sem termos como socorrer a Vida.

Chegou a hora de defender a vida do fogo da morte. Defender a vida como Tupã nos entregou: a vida dos rios, das matas, dos pássaros, de todos os animais, das nossas crianças! Nessa luta pela vida necessitamos contar com o compromisso, a união, a força e a coragem de todas as mulheres, homens e crianças de nosso Grande Povo Guarani.

Nossos povos irmãos que também nasceram desta terra, e há mais de quinhentos anos resistem em seus sonhos, cantos, rezas, danças e línguas, também devem lutar pela vida. A lembrança dessa terra imaculada está na memória das pedras, das águas e do sangue que corre nas veias de cada morador deste continente. Em defesa da vida e da terra fazemos um convite para que cada um resgate essa memória, conheça nossa cultura e lute conosco para traçar juntos o caminho para um futuro de liberdade. O Horizonte é a meta, caminhar juntos é o objetivo.

É interessante a Nhe"e (fala, discurso) proferida pela Nhandecy (nossa mãe) Kunhã Karaí Tatati, registrados por (CICCARONE, 2001, p. 80) num Tekoá (lugar de mo- 
rada) no estado do Espírito Santo, elucidam e apontam para os transtornos e dificuldades a serem superadas pelo Guarani, quando da tentativa de levantar um novo Tekoá (lugar de morada), chama a atenção dos seus para os procedimentos em relação ao modo de ser, ao Nhandeteko (modo de ser), a ser fortes, resistententes, não desanimar, ter uma constância de fé, crença nas orientações de Nhanderú Ete (nosso deus verdadeiro). Ouvir o que os mais velhos aconselham aos mais novos para tomar cuidado com as coisas dos Juruá (branco):

Vocês precisam ser fortes e unidos. Terão com os brancos muitas dificuldades em relação à terra. Precisa ter firmeza, ficar mais, morar anos e anos no mesmo lugar. Tem que cultivar muito, fazer plantios, plantar milho, mandioca (...) para que não falte alimento na aldeia e as crianças desfrutem disso. Antigamente tinha espaço livre para andar e hoje é diferente. Os brancos se apoderam da terra como se fossem donos, mas eles não são os donos, o dono verdadeiro é Ñande Ru Tenonde, ele é o verdadeiro dono e é ele que decidirá sobre a terra, ele sabe como está a terra. Nós, filhos caçulas, temos que morar, construir uma aldeia no meio dos matos e viver bem, em paz, juntos e em harmonia com a natureza porque isso foi o que Ñande ru mostrou para nós, para nós viver deste jeito. Viver de acordo com que Ñande ru, o pai verdadeiro e Nande-cy, a mãe verdadeira, criaram. Onde a gente viver e ficar bem, morar bem juntos, vive bem Ñande ru koa pona (o todo da aldeia vive bem), para que todas as criancinhas vivam felizes e saudáveis. Ñande ru fez a terra para todos os filhos dele e os brancos devastaram os matos, destruíram quase tudo e o pouco que restou, aquele que é bom já tem dono, os brancos levaram tudo e hoje em dia é difícil achar um lugar que convém, que é bom para os Guarani.

As metáforas utilizadas para indicar as características da mãe terra, são geralmente ligadas ao corpo humano, conectadas com as funções primárias de comer, descansar e se alimentar. Os rituais do Nemongarai (batismo) e os Jeroky (danças) têm por função mantê-la com a saúde equilibrada, livre de doenças ou qualquer outro mal, razão das longas Nhembo"e (orações) e os Porahei/Mboraei (cânticos de invocação), que atravessam a noite. A intenção é manter o equilíbrio cósmico, embora a proeminência da catástrofe guie os discursos com ares de advertência moral, recordando que há uma ética no Nhandereko (modo de ser), que deve ser estritamente observada ou se terá não só a terra adoecida, enfraquecida, corroída de dores, como também os seus habitantes Mbyá.

É interessante o discurso do parente guarani Wilsom Changaray ao também indígena (Aimara) e presidente da Bolivia Evo Morales em 2006: 


\begin{abstract}
Esta terra livre, independente e soberana tem que se basear nos princípios fundamentais indígenas. Princípios que superam os interesses pessoais e transcendem e abraçam as esferas do social econômico, cultural e político. Estes princípios são a essência fundamental do ser Guarani, como a busca incessante da Terra Sem Males e da Liberdade. Mas, quem me responde? Nem Deus me responde quando vou ser livre...!!! Nossa essência é de ser sem dono "... o Deus nosso é a Natureza e não a Lei...." Princípios que impregnam o ser social, como a Mboroaiu, Mborerekua, Yoparareko, esse amor, estima, carinho, solidariedade, expressada em sentimento ao próximo, que permite superar e desprender-se do ser mesquinho e individualista.
\end{abstract}

O modo como o pensamento Mbya Guarani (re)elabora, a representação de si e a relação com o(s) outro(s), na caminhada ou durante uma pausa na mesma, nos acampamentos temporários, são alinhadas com o imaginado, o sonhado, o projetado, o suposto e o "profetizado", estes espaços liminares, da imaginação, não são aleatórios, soltos, mas vinculados a elementos prévios, pressupostos sobre o que é o real (CRAPANZANO, 2005).

A relação pode ser tensa e contraditória considerando o domínio do espaço físico, cultural, a modernidade, as novidades tecnológicas que tanto atraem a nova geração, se elabora explicações sejam elas filosóficas ou mitológicas, sobre o mundo, o lugar em que se encontra, sobre a natureza e sobre o lugar que nele o homem ocupa. O guarani entende essa relação como vínculos de continuidade que perpassam as esferas do social, da natureza e dos humanos e não humanos. As interações sociais abrangem mais do que o espaço da humanidade em si, abarca os animais, as plantas e os entes que compõem o cosmos. Nessa óptica são entendidos como sujeitos sociais, que se comportam como se humanos fossem, a diferença é que fazem parte do mundo que olhos não vêem. Possivelmente como afirma (DESCOLA, 2000), a diferença entre humanos e não-humanos são de grau, e não de natureza. As plantas e animais têm seu espírito ou uma alma que se comunica com humanos.

Assim Nhanderu Tenonde (nosso pai primeiro), criou o mundo, formou as imensas florestas, deixando-as aos cuidados dos Mbya, nestas matas habitam seres dotados de muitas intencionalidades, sendo necessário que seja estabelecida relações sociais, onde sejam respeitados os limites de um e do outro, as alteridades se impõe para uma boa convivência entre os dois mundos. O que deve ser respeitado nessa relação entre humanos e não-humanos é a hierarquia existente entre os seres destes mundos e estas 
intencionalidades, com capacidades de agência (agentivas), pois estão distribuídas de maneira desigual no cosmos (GELL, 1998; FAUSTO, 2002).

De acordo com (PISSOLATO, 2007), o domínio das relações é entre humanos e deuses, cujas relações com outros seres do cosmos devem ser controladas, uma vez que poderiam resultar na transformação do Guarani, enquanto afastamento da sua condição humana ou perda da sua humanidade. Isto requer o cumprimento de regras e normas sociais, orientadas pelos seus antepassados, através do Karai (liderança religiosa masculina) e Kunha Karai (liderança religiosa feminina), mas sem deixar de considerar o respeito à liberdade de cada um, de estar no mundo que lhe pertence. De acordo com (SILVA, 2007), tanto os Mbya quanto os Nhandeva referem-se aos seus corpos de duas maneiras: Xe Rete [meu corpo], tratando-se do corpo físico, sua forma e as partes que o compõem, e Xe Yvyra [minha madeira], termo, geralmente, utilizado em contexto religioso quando se quer marcar distinção em relação à matéria que constituiu os corpos de outros seres.

No entanto essas relações e outros aspectos que envolvem os rituais na Opy (casa ritual), que perpassam pelos caminhos do Arandu (sabedoria), dessa cosmopolitica, é praticamente infinita, com muitas vozes proferidas em sunsurro e que são mantidos na esfera do segredo. Nesse sentido é a fala de Werá Guarani em uma de nossas conversas na frente de sua casa:

Com Juruá, é muito diferente o causo né! É por isso que não podemos falar muita coisa de nossa religião e nem pra ninguém! Tu sabe né, tu é avá guarani ou como dizem nhandeva, mais é igual nóis Mbya, conhece o nhande reko'á. Juruá duvida de nóis, é sempre assim, pergunta, escreve, ele pensa que o índio guarani tem que explicar tudo. Eu falo das coisas do antigo, aprendi com meu pai, coisas da cultura né, da opy'í, mas eu acho que não acreditam nos índios porque eles não vivem igual nóis, não pensam como nóis!presta bem atenção, tu tem que toma cuidado pra não ficar igual Juruá, tem que fica mais com noís na opy'í. Tu sabe que da nossa religião, não pode fala muito porque tem parte que é segredo e se fala Nhanderu pode não gosta.

O Mbya procura manter os aspectos de sua crença, restritos nos espaços da opy (casa ritual) e os aspectos mais sacros, íntimos, somente com outro guarani comenta ou conversa sobre dogmas da sua crença.

Portanto, a partir deste registro etnográfico apresentamos outra faceta que se 
mostrou e mostra repleta de encontros e desencontros, encantos e desencantos, identidade e alteridade, diferença e desigualdade, povo aculturado e tradicional, cultura que conecta ou separa pessoas, sujeitos, por meio de marcadores étnicos, inibindo as especificidades de cada etnia, reforçando o olhar etnocêntrico sobre o outro, diferente. Assim, com esta descrição propusemos apresentar o diferente como diferente, nem melhor e nem pior, apenas um diferente que precisa de mais respeito.

\section{Referências}

CADOGAN, Leon. [1959] 1992 - Ayvu Rapyta - textos míticos de los Mbyá-Guarani del Guairá. Asunción, Fundación León Cadogan, Ceaduc/Cepag.

CHAMORRO, Graciela. 2008. Terra madura, yvy araguyje: fundamento da palavra guarani. Dourados, MS: Editora da UFGD.

CICCARONE, Celeste. 2001. Drama e sensibilidade: migração, xamanismo e mulheres Mbyá Guarani. Tese de doutorado. Programa de Pós-Graduação em antropologia, Pontifícia Universidade Católica. São Paulo.

CLASTRES, Helene. 1978. Terra sem mal. Editora brasiliense. São Paulo.

CRAPANZANO, Vincent. 2005. Horizontes imaginativos e o aquém e além. Revista de Antropologia, São Paulo, v. 48, n. 1, p. 363-384, jan./jun.

. 1990. A Sociedade contra o Estado. 5. ed. Rio de Janeiro: Francisco Alves.

DESCOLA, Phileppe. 2000. Ecologia e Cosmologia. IN: DIEGUES, Antonio Carlos (org). Etnoconservação: Novos rumos para a conservação da natureza. São Paulo: HUCITEC/NUPAUB-USP, pp. 149-163.

FAUSTO, Carlos. 1992. 2002. Banquete de Gente: Comensalidade e Canibalismo na Amazônia. IN: Mana 8(2): 7-): 7-44.

GELL, Alfred. 1998. Art and agency: an anthropological theory. Oxford: Clarendon Press.

LADEIRA, Maria Inês. 1984. Aldeias Livres Guarani do Litoral de São Paulo e da Periferia da Capital. In "Indios no Estado de Sào Paulo: Resistência e Transfiguração" , vários autores, Yankatu, CPI-SP, 1984.

LÉVI-STRAUSS, Claude. Anthropologie structurale II. Paris: Plon, 1973.

Le regard éloigné. Paris: Plon, 1983.

2001a. Race et histoire et Race et culture. Prefácio de M. Izard. Paris: Editions de I'UNESCO. Edição brasileira em LÉVI-STRAUSS, Claude. "Raça e história", In: 1989. Antropologia estrutural II. Rio de Janeiro: Tempo Brasileiro, pp. 328-366.

LITAIFF, Aldo. Os filhos do sol: mitos e práticas dos índios Mbya- Guarani do litoral brasileiro. Tellus, Campo Grande, v. 1, n. 6, p.15-30, abr. 2004.

.1999. Les Fils du Soleil: mythes et pratiques des indiens mbyá-guarani du littoral 
du Brésil. Tese de doutorado em antropologia. Universidade de Montréal. Canadá. 1999. MÉTRAUX, Alfred. 1979. A religião dos Tupinambás e suas relações com as demais tribos Tupi-Guarani. São Paulo: Companhia Editora Nacional, Editora da Universidade de São Paulo.

MELIÁ, Bartomeu. 1988. La vida en las reduciones jesuiticas de guaraníes o el uso perfecto del tiempo In: El Guarani conquistado y reducido: ensaios de etnohistória. Asunción: Universidad Católica.

.1991. El guarani: experiência religiosa. Asunción: CEADUC-CEPAG.

27-34. 1997. Mito y Educación. Estudos Leopoldinenses, Série Educação, vol. L nº I,p.

MELLO, Flávia Cristina de. 2001. Aata tape rupy - Seguindo pela estrada, uma investigação sobre os deslocamentos territoriais realizadas pelas famílias Mbyá e Chiripá Guarani do sul do Brasil. Dissertação de mestrado. Programa de Pós-Graduação em Antropologia Social, Universidade Federal de Santa Catarina.

MONTARDO, Deise. 2002. Através do Mbaracá. Música e xamanismo Guarani. Tese de doutorado. Programa de Pós-Graduação em Antropologia Social. USP. São Paulo.

MONTEIRO, John Manoel. 1998. Os Guaranis e a historia do Brasil meridional: Séculos XVI - XVII. In: Cunha, Manoela Carneiro da (Org.). História dos índios no Brasil. São Paulo: Companhia das letras.

NIMUENDAJU, Curt. ([1914] 1987). As Lendas da Criação e Destruição do Mundo como Fundamentos da Religião dos Apapocuva-Guarani. São Paulo: HUCITEC e EDUSP, 1987.

PEREIRA, Levi Marques. 2004. A socialidade na família kaiowa: relações geracionais e de gênero no microcosmo da vida social. IFCH, UNICAMP. Mimeografado, 2004.

PISSOLATO, Elisabeth. 2007. A duração da pessoa: mobilidade, parentesco e xamanismo Mbya (Guarani). São Paulo: Editora UNESP: ISA; Rio de Janeiro: NuTi.

RIBEIRO, Darci. 1996. O Povo Brasileiro. São Paulo: Companhia das Letras.

RUIZ DE MONTOYA, Antonio. 1876c. Tesoro de la lengua guaraní [1639]. Leipzig, Oficina y Funderia de W. Drugulin.

SCHADEN, Egon. ([1962] 1972, 1974). Aspectos fundamentais da cultura Guarani. São Paulo: Difusão européia do livro.

\section{Edusp.}

([1945] 1989). A Mitologia Heróica de tribos indígenas do Brasil. São Paulo :

SILVA, Evaldo Mendes da. 2007. Folhas ao vento. A micromobilidade de grupos Mbyá e Nhandéva (Guarani) na Tríplice Fronteira. Tese de doutorado em antropologia Social. Museu Nacional da Universidade Federal do Rio de Janeiro. Rio de Janeiro.

SOUZA LIMA, A. C. 2002. Diversidade cultural e política indigenista no Brasil. In Tellus. $n^{\circ} .3$, p. 04.

SUSNIK, B. 1965. El guaraní colonial. Asunción, Museo Etnográfico "Andrés Barbero" . 
(El Indio Colonial del Paraguay, 1).

TAUSSIG, Michael. 1993. Xamanismo, colonialismo e o homem selvagem. Um estudo sobre o terror e a cura. Rio de Janeiro, Paz e Terra. 